\title{
閉鎖型苗生産システムの開発およびその利用
}

\author{
大山克己 ${ }^{1} \cdot$ 古在豊樹 $^{2} \cdot$ 全 昶厚 ${ }^{2}$ \\ ${ }^{1}$ 日本学術振興会特別研究員 \\ 2 千葉大学園芸学部 271-8510 千葉県松戸市松戸 648
}

\section{Development of Closed-type Transplant Production System and Its Application}

\author{
Katsumi OHYAMA ${ }^{1}$, Toyoki KozAI ${ }^{2}$ and Changhoo $\mathrm{CHUN}^{2}$ \\ ${ }^{1}$ Research fellow of the Japanese Society for the Promotion of Science \\ ${ }^{2}$ Faculty of Horticulture, Chiba University, Matsudo, Chiba 271-8510, Japan
}

\begin{abstract}
The closed system is defined as a warehouse-like structure covered with opaque thermally insulated walls, multi-shelves with lamps, home-use air conditioners, and other equipments for water and $\mathrm{CO}_{2}$ supply. Environments inside the closed system are not disturbed and thus can be controlled as desired. Ventilation is restricted at minimum to minimize resource consumption and environmental pollution, and to prevent insects and/or pathogens from entering into the system. It was estimated that the initial cost for construction of the closed system per transplant could be the same as that of the open system (i.e., greenhouse). Optimally controlled environments in the closed system enhanced the growth and development of several transplants so that the production period in the closed system was reduced by 10 to $50 \%$, compared with that in the open system.

Electric energy consumption per transplant in the closed system was $0.3-0.6 \mathrm{MJ}$, and its cost was 1-2 Japanese Yen. Water and $\mathrm{CO}_{2}$ consumptions in the closed system were, respectively, about $1 / 15$ and $1 / 5$ of those in the open system. Transplant quality (vigor, growth uniformity, controlled flower development, etc.) was higher in the closed system than in the open system. We concluded that high quality transplants could be produced within a significantly shorter period and with less consumption of resources in the closed system than in the open system. Hence, the closed system was economically competitive over the open system for many horticultural, medicinal and other crops.
\end{abstract}

Keywords : initial cost, production period, quality of transplants, resource consumption, ventilation

はじめに

21 世紀に扔ける環境劣化, 石油資源および食料の不 足に関する地球規模的問題の解決に貢献するためには, 植林緑化植物, 石油代替植物, 園芸作物, 工芸作物, 食 料作物などの苗が大量に必要とされる ${ }^{11}$.これらの苗を

2002 年 10 月 1 日受付

2002 年 10 月 26 日受理
省資源的, 環境保全的, 省力的, かつ安定的に大量生産 するためには, 従来とは発想と基盤技術が異なる革新的 な苗生産システムの開発が必要である ${ }^{2,3)}$. 筆者らは, 上記の背景にもとづいて，閉鎖型苗生産システムの開発 研究を行っている ${ }^{420)}$. 現在までに, 閉鎖型苗生産シス テムを用いて高品質な苗を 1 本あたり 1-2 円程度の電気 料金で, かつ必要最小限の資源で, 生産できることを示 唆した。また，システム内の環境調節により，従来より も高付加価値化した苗を生産できることを実証した．本 稿では, 筆者らの研究グループにおける成果を紹介しつ 
つ, 閉鎖型苗生産システムの定義や具体例を紹介し, 従 来の苗生産で用いられている自然光利用の温室と比較す る.

\section{定義}

内外の物質(水, $\mathrm{CO}_{2}$ など)交換が最小限となるよう に制御された, 光に不透明な断熱壁に囲われた建物内で, 人工光を利用して植物を生産するシステムを閉鎖型植物 生産システムと呼び，その利用を苗生産に限定した場合 を閉鎖型苗生産システム(以下，閉鎖型システム) と呼ぶ。 他方, 閉鎖型植物生産システムと比べて内外の物質交換 が制御されていない建物 (例えば，自然光利用の温室）と その付属設備からなる生産システムを開放型植物生産シ ステムと呼び, その利用を苗生産に限定した場合を開放 型苗生産システム (以下, 開放型システム) と呼ぶ。なお, 従来の研究と比較した場合, 完全制御型植物工場のうち, 内外の物質交換が最小限となるような概念にもとづき設 計された植物工場のみが閉鎖型植物生産システムに分類 され, 従って, 大半の植物工場(例えば, 太陽光利用型 植物工場) は開放型植物生産システムに分類される.

\section{苗生産を目的とする理由}

筆者らの研究グループでは，閉鎖型システムにおける 苗生産に着目している。これは，1)一般的に栽植密度が 500- 2500 本 $/ \mathrm{m}^{2}$ と高い，2) 最適光強度が比較的低く, 光合成有効光量子束 (以下, PPF) で表すと 100-350 $\mu \mathrm{mol} \mathrm{m}{ }^{-2} \mathrm{~s}^{-1}$ 程度である(幅 $60 \mathrm{~cm}$ の棚で $30-40 \mathrm{~cm}$ 程 度の距離から蛍光ランプにより近接照射した場合, その 管数は 3-6 本で上述の PPF を実現可能)，3) 草丈が短 く, 蛍光ランプを用いた場合には近接照射が可能であ る きる(苗の移動を人手で行なう場合 4-5 段程度, 搬送装 置などで行なう場合はそれ以上)，4）近接照射されてい て, かつ PPF や気温, $\mathrm{CO}_{2}$ 濃度などの環境条件が適切 に制御されていることから, 光利用効率(投入エネルギ 量に対する光合成による固定化学エネルギ量の百分率) が高い，5) 環境調節による苗品質向上と成長促進が容易 である，6)生産の計画・調整がしやすい，からである.

閉鎖型システムにおいては，自然光を利用した開放型 システムでは実現困難な環境にも制御できることから， それを利用してさらなる苗の成長促進や高付加価值化, 電力コストの削減などが可能となる．例として，1) 低光 強度でも日長を 16-24 時間と延長することで，従来と同
等の苗を生産できる $\left.{ }^{23)} ， 2\right)$ 連続明期下でも変温処理と組 み合わせることで，ナス科植物でも従来と同様の苗の生

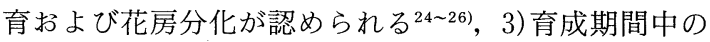
暗期の気温を低下させることで，夏季においても適切な 位置にトマトの第 1 花房を分化させられる27)，4)電気料 金の安価な時間帯にのみ強光を照射して苗を育成でき る28),ことなどがあげられる。

他方，これまでの環境条件と植物の生育との関係を調 べた研究では, 自然環境下における植物の生育反応に関 する知見が主であり，自然環境下では起こりえない条件 下でのそれは少ない. 今後, 閉鎖型システムを用いてい く上で，そのような環境下での植物成長に関する研究が 必要となってくると考えられ，その研究を開始した。 こ れまでに，日長を 48 時間にした場合の苗の生育 ${ }^{29}$ ，明 暗や気温の非周期的変動が苗の生育におよぼす影響 30,31 , 日長を 24 時間に限定しない条件下でのホウレンソウの 抽だい ${ }^{32,33)}$ ，に関しての知見が得られた。

閉鎖型植物生産システムで苗以外の植物を生産するこ とは, 外界の気象条件に影響されずに生産できるといっ た点で大きな魅力ではある。しかし，苗生産の場合と異 なり，1)最適 $\mathrm{PPF}$ が比較的高い $\left(300 \mu \mathrm{mol} \mathrm{m}^{-2} \mathrm{~s}^{-1}\right.$ 以 上), 2) 栽植密度が低い，3)苗と比べて草丈が長いので 近接照射が難しい，4）育苗期間と比べて栽培期間は通常 長い，5) 果菜類の場合は可食部よりも植物体全体に占め る非可食部の百分率が高い，といった人工光源を利用す る上での短所も存在することから，現在のところ，上記 の短所の影響による生産コストの上昇が比較的小さい葉 菜類の生産において実用例(例えば，キューピー(㑣)の TS ファームなど)が見られるだけである. 今後, 技術 的な進歩および社会的状況の変化によりトマトなどの果 菜類の生産を目的とした閉鎖型植物生産システムが実用 化する可能性もあるが, 現状では, 販売価格の高い薬用 植物や高級園芸植物 (イチゴ, ラン，ハーブなど)，特殊 工芸作物 (サフランなど)などがその候補となるにとどま る.

\section{閉鎖型システムの具体例}

本稿では, 閉鎖型システムの具体例として, 千葉大学 園芸学部 (千葉県松戸市) 内にある大規模生産用システ $\Delta^{34)}$ とその $1 / 10$ の生産能力に相当する農家普及用シス

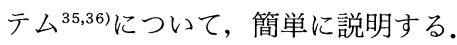

\section{1. 大規模生産用システム}

現在, 千葉大学園芸学部内に, その実証研究を目的と した閉鎖型システムがある.このシステムは, 研究用設 
備と苗生産用設備とにより構成されている. 研究用設備 として, 生物工学系および物理工学系の測定および作業 用の実験室が 5 室設けられている. 苗生産用設備は, ク リーンエリアと非クリーンエリアに大別される。クリー ンエリアには, 苗育成空間である培養室および 2 つ䏍 苗室, 貯蔵の際に利用される低温貯蔵室, および植付け などの作業のための作業室により構成される。他方, 非 クリーンエリアには, システムを運営・管理するための コンピュータなどが配置されている制御室, 作業の準備 を行なう準備室, 貯蔵もしくは出荷の際に通過する低温 貯蔵室, 器具やトレイなどの洗浄に用いられる洗浄室, および制御機器などが設置された機械室により構成され る。そのほかに，居室や管理主任室などが設けられてい る. 培養室および育苗室には, それぞれ 2 および 4 台の 基本モジュールが設置されている。基本モジュールは, 蛍光ランプ, エアコン, ファン, 加湿器および 7 段の育 成棚により構成される. 実験室内の育成棚の各段には, 光源として $32 \mathrm{~W}$ 白色高周波蛍光ランプが 16 本, $16 \mathrm{~W}$ 白色高周波蛍光ランプが 3 本それぞれ設置されている. 家庭用エアコンは基本モジュールごとに 3 台設置され, エアコンの吹き出した空気とファン周辺の空気がファン により混合された後, 各育成棚にほほ均一に送り込まれ る. その結果, 比較的均一な環境制御結果が得られ, ほ ぼ均一に苗は生育する ${ }^{37)}$. 1 台の基本モジュールで 56 枚のトレイを収容することができるので, 育苗期間を 2 -3 週間とし, 通年稼動した場合, 年間でトレイにして 9500-14600 枚のセル成型苗を生産できる.これは, ト レイあたりのセル数が 72 穴の場合は70-100万本に, 400 穴の場合は 380-580万本にそれぞれ相当する.トレ イの移動は自動倉庫などで利用されている搬送装置を用 いている。この搬送装置は, 培養室および育苗室にそれ ぞれ 1 台ずつ設置され, 他方, かん水装置も設置されて いるので, かん水時にも利用される. かん水装置として は, 噴射式底面かん水装置 ${ }^{38,39)}$ が採用され, より高度な 培地水分管理が可能となっている ${ }^{40,41)}$. 建物の屋上には 太陽熱温水器が設置されていて，そこで作られた 70$80^{\circ} \mathrm{C}$ の温水がトレイの洗浄などに利用される。これま でに, 閉鎖型システムにおけるエネルギおよび物質収支 の解析結果より, 省資源・省エネルギ的な苗生産が可能 であることが示唆されている42 48). 他方, システムの 運用・管理のために, 自律分散制御を利用したソフトウ エア ${ }^{49 \sim 56)}$ も導入されている. 苗個体群の成長管理用シ ステムとして, 双眼カメラを利用して苗個体群の成長度 を測定するための画像計測システム ${ }^{57)}$ が用いられている. 現在, ニューラルネットワークを利用した成長量予測精
度の向上も図られている58).

\section{2. 農家普及用システム}

最近になり，比較的小規模な閉鎖型システムの開発も はじめられている.このシステムでは, 全体で 48 枚の トレイを収容でき, 気温および $\mathrm{CO}_{2}$ 濃度は自動的に調 節される.トレイの移動は人手により行なうことを前提 としている. かん水には, 底面式自動かん水装置 ${ }^{59)}$ を用 いられる。育苗期間を 2-3 週間とし，通年稼動した場合， 年間でトレイにして 800-1300 枚のセル成型苗を生産で きる.このシステムは, 前述の大規模システムの $1 / 10$ 程度の生産能力であり, 年間のセル成型苗生産数はトレ イあたりのセル数が 72 穴の場合は 6-9 万本に, 400 穴 の場合は 30-50万本にそれぞれ相当する.

\section{主要構成要素ととの特徵}

閉鎖型システムの主要構成要素は, 光に不透明な断熱 材で囲われた構造物, 蛍光ランプ, 多段棚, エアコン, 空気循環ファンおよび $\mathrm{CO}_{2}$ 施用装置である. 閉鎖型シ ステムでは, 開放型システムの主要構成要素である, 温 室構造物, 暖房装置, 換気装置, 保温カーテン, ベン チ・ベッドは不要である. かん水装置, 総合環境制御装 置は両システムに共通な構成要素である.

閉鎖型システムにおける PPF と明期は, ランプの点 灯数と点灯時間の調節で正確に制御できる. 気温などの 環境条件も, システム外の天候による影響をうけること なく高精度に制御できる. 他方, 開放型システムでは, PPF の調節精度は遮光装置と補光装置を用いても不十 分であり，また，明期を自然日長より短縮するのは困難 である。気温もシステム外の天候による影響をうけやす く，高精度に制御するためには大量のエネルギ投入を必 要とする.

\section{家庭用電化製品を用いることの利点}

筆者らの研究グループでは, 閉鎖型システムの構成要 素として，家庭用電化製品および一般建築用部品を用い ることを想定している。これらは, 高性能かつ低価格な ためであり, また, 廃棄時のリサイクルシステムが確立 されているからである。

蛍光ランプの発光効率(ランプの消費電力あたりの光 束 $\left.\left(\operatorname{lm~W} \mathrm{W}^{-1}\right)\right)$ は，ここ 20 年間で $50 \%$ 向上している ${ }^{60)}$. 発光効率の向上は, 主にインバーターの導入とハロゲン 化希土類蛍光体の利用による. また, 蛍光ランプの平均 寿命は 3000 時間から 12000 時間になった. 他方, 蛍光 
ランプ内に封入されている環境污染物質である水銀の量 の削減が取り組まれ，従来のそれよりも $30 \%$ 程度削減 された。他方，リサイクルシステムも完成されている.

家庭用エアコンの節電技術も，大幅に向上してきてい る. 家庭用エアコンに関して, 平均年間消費電力量は, 1994 年から 1998 年の 5 年間で, $50 \%$ 低下し, 定格電力 は 70\%に低下した ${ }^{61)}$. その結果，家庭用エアコンの冷 房時成績係数は, 日本工業規格で定められた標準条件下 (室内 $27^{\circ} \mathrm{C} /$ 室外 $35^{\circ} \mathrm{C}$ ) で, 2.5 程度から 4 程度にまで向 上した。この理由として，1)インバーターの導入，2) モー夕の性能向上，3)熱交換機の性能向上，なぞがあげ られる. 現在では, 冷房時の成績係数が 6 近くにまで高 められた製品も販売されはじめている，他方，家庭用工 アコンは, 特定家庭用機器再商品化法, いわゆる家電り サイクル法の施行に起因して，リサイクルに対する配慮 がなされるようになり, 冷媒 $(\mathrm{R}-22)$ の廃棄処理システ ムの開発や代替フロン $(\mathrm{R} 410 \mathrm{~A})$ の導入が図られている.

閉鎖型システムと比較して, 開放型システムの構成要 素はどうであろうか. 現状では，施設園芸に特有な製品 であり, 家庭用電化製品に比較して技術進歩が遅く, 高 価である、また，リサイクルシステムが確立されていな いので, 廃棄処理コストが高くなる. 今後, 環境負荷に 対する課金が発生した場合には，システムの建設から廃 棄までの一連のコストを考慮すると，閉鎖型システムの 方が開放型システムよりも低コストとなりうる.

\section{生産性の向上}

開放型システムと比較して, 閉鎖型システムは以下の ような利点を有するために，単位面積あたりの生産性が 向上すると考えられる，1)多段棚の利用により，床面積 あたりの育苗面積を 2.5 倍以上にできる (育苗面積/床面 積比の例：開放型システム，0.7-0.8；閉鎖型システム, 2.5-3.0)，2）通風と低相対湿度により，育苗密度を 1.5 倍以上に増やしても, 苗質の低下は認められない $\left.{ }^{62}, 3\right)$ システム内の環境調節が比較的正確に行われることによ り苗の生育がそろい ${ }^{37)}$, 苗商品化率を $10 \%$ 以上向上で きる可能性がある(例：開放型システム, $85 \%$; 閉鎖型 システム, 95\%). 上記の 1)-3)の数值にもとづくと, 閉鎖型システムでは開放型システムに比較して, 1 回の 単位面積あたりの苗生産数を 4 倍以上 $(=2.5 \times 1.5 \times$ 1. 1) に増大できうる.

さらに, 4) $\mathrm{CO}_{2}$ 濃度, 光強度, 明期, 気温などの環 境調節により, 育苗日数を $10-50 \%$ 短縮できる ${ }^{62 \sim 64)}$, 5) 閉鎖型システムは外界気象にかかわらず周年利用でき
ることから，年間の稼動日数を $10 \%$ 以上増やすことが できる，といったことにより生産性が向上すると予想さ れる.

前述した 1 回の単位面積あたりの苗生産数が 4 倍とな ることに加えて, 育苗期間が $25 \%$ 短縮でき, 稼働日数 を $10 \%$ 増大させることができると仮定した場合, 閉鎖 型システムは開放型システムに比較して, 年間で床面積 あたり苗生産数を約 6 倍 $(=4 \times 1.1 \div 0.75)$ に増大でき る. 後述するような苗品質の向上により, 閉鎖型システ ムで生産した苗の販売価格は開放型のそれょり約 $10 \%$ 高くできるとした場合, 床面積あたり生産額は開放型シ ステムに比較して約 7 倍になる。他方, 開放型システム に比較して, 閉鎖型システムでは, 快適な労働環境での 作業だけではなく，作業面積が $1 / 6$ に減少することにと もなう人や物品の移動距離削減との相乗効果により, 労 働生産性は $10 \%$ 以上高まると予想される。

\section{初期施設設 備費}

上述のように，閉鎖型システムは，開放型システムに 比較して, 年間の床面積あたり苗生産能力を約 6 倍以上 にできると予想される。 それゆえ, 閉鎖型システムの苗 生産数あたりの初期施設設備費は, 開放型システムのそ れと比較して，現在でも同等もしくはそれ以下であろう。 現在, 日本におけるガラス室の建屋価格は 25,000 円/ $\mathrm{m}^{2}$ 程度である。 また, 保温カーテン, 遮光カーテン, 換気装置, かん水装置, 細霧冷房装置, 温風暖房装置, ベッド・ベンチなどの設備価格は, 各数千円 $/ \mathrm{m}^{2}$ である ので, 建物と装置の合計価格は 50,000 円 $/ \mathrm{m}^{2}$ 程度であ る。例をあげると, $300 \mathrm{~m}^{2}$ の育苗ガラス室の初期施設 設備価格は 1,500 万円になる. 他方, 年間苗生産数が上 記開放型システム (育苗ガラス室)の同等な閉鎖型システ ムの床面積は $50 \mathrm{~m}^{2}$ であり, 現在, 床面積 $50 \mathrm{~m}^{2}$ 閉鎖型 システムの初期施設設備価格は $1,000-1,500$ 万円程度 $\left(20-30\right.$ 万円 $\left./ \mathrm{m}^{2}\right)$ 以下であるので, 閉鎖型システムの初 期施設設備費は開放型システムのそれと同等以下となる. あわせて，上記の仮定の下で閉鎖型システムを用いた場 合では, 土地面積を $250 \mathrm{~m}^{2}(=300-50)$ 節約できるので, その土地を他用途に活用できる。

閉鎖型システムが普及して量産が開始された場合，家 電製品・断熱材のメーカーまたは問屋からの大量一括購 入による $50 \%$ 以上の值引きが通常可能であることから, 閉鎖型システムの初期施設設備費は現在の $1 / 2$ 以下とな る.なお，家庭用エアコンの販売価格は，業務用エアコ ンのそれと比較して $1 / 3$ 程度 (家庭用エアコン: 約 20 万 
円，業務用エアコン：約 60 万円)であり，また冷房時の 成績係数(電気消費量あたりの冷房能力) は約 2 倍(家庭 用エアコン: 約 6, 業務用エアコン: 約 3), すなわち電 気消費量は約 $1 / 2$ である。ただし，前述の成績係数は日 本工業規格で定められた標準条件下 (室内： $27^{\circ} \mathrm{C} /$ 室外： $\left.35^{\circ} \mathrm{C}\right)$ で求められたものであり, 実際に稼動した場合に は夏季においてもそれよりも大となり, 電気エネルギ消 費量は少なくすむ65).

\section{苗品質の向上}

苗品質は，外観品質と生理的な特性にもとづく品質と に大別される. 外観品質とは, 大きさ, 葉色, 質感など であり，また，生理的な特性にもとづく品質とは，花芽 の分化が開始されている，移植後のストレスに耐えうる だけの貯蔵養分が含まれる，ことなどが例としてあげら れる、閉鎖型システムでは，1)高育苗密度でも，コンパ クトで強健な苗が，トレイ間およびトレイ内で均一に生 育する ${ }^{37,63)}$ ，2) サツマイモでは単節単葉を外植体として 2 週間でセル成型苗のような小苗に仕立てることができ る ${ }^{66)}$, といった一般的な外観品質の向上が見られるだけ でなく，3）トマトでは葉位 8 段目に第 1 花房が確実に分 化発育し, 早期収穫, 増収が可能になる $\left.{ }^{27,62)}, 4\right)$ ホウレ ンソウなどでは夏期の収穫時に抽だいしない苗にな る67 71)，5）トルコキキョウなどでは出荷時に抽だいし ている苗になる $\left.{ }^{72)}, 6\right)$ パンジーでは花芽分化・開花が早 期に開始した苗ができる73,74)，といった苗として望まれ る生理的特性をもつ，すなわち付加価值がある苗を生産 できることが実証されている．これらの苗の高付加価值 化は, 開放型システムでは困難であるか, 大幅な生産コ ストの上昇を引き起こすと考えられる. 苗の高付加価值 化は, 閉鎖型システムで生産した苗の開放型生産システ ムで生産したそれに対する差別化, ひいては高価格で販 売する上での一つの手法となる.

\section{電気エネルギ消費量および電気料金}

閉鎖型システムは厚さ 100-150 mm 以上の断熱壁で覆 われ，かつ換気が抑制されているので，夏期でもシステ ム外から壁を通しての熱侵入はほとんどなく，また，冬 期の暖房は, 外気温がー $5-0^{\circ} \mathrm{C}$ 程度であれば不要である. 年間電気エネルギ消費量の内訳は, 照明 65-75\%, 空調 15-20\%，ポンプ・空気循環ファンなど5-20\%であ る ${ }^{42,43,75)}$. 苗あたりの電気エネルギ消費量は $0.3-0.6$ MJであり, 平均的な苗販売価格 50 円程度に対して,
苗あたりの電気料金は現在 1-2 円である ${ }^{76)}$.トレイあた りの苗数が多くなるほど苗あたり電気料金は小となる. また，環境調節による育苗期間の短縮によっても，苗あ たり電気料金は削減できる.

閉鎖型システムの電気エネルギ消費量を節減していく 上で, 高性能な要素技術を採用していくことは必須であ る.また，それぞれの要素が十分に性能を発揮できるよ うにシステムを設計することも必要である。とくに，照 明システムに関しては, その電気エネルギ消費量が全体 のそれに占める百分率が高いことから, 適切なランプの 本数, 配置, 反射板の設置といった, 照明システムの適 切な設計が重要である.

\section{か人水量, 施用 $\mathrm{CO}_{2}$ 量, 施肥量 および農薬使用量の節減}

閉鎖型システムでは, 以下のような理由により, 開放 型システムと比べて, かん水量, 施用 $\mathrm{CO}_{2}$ 量, 施肥量 および農薬使用量を節減することが可能である．1)換気 量が小さいために，システム外への水損失がほとんど無 い，2)苗・培地から蒸発散した水はエアコンの冷却コイ ルで凝結し集められ，それをかん水に再利用することに より，その必要量が約 $1 / 5-1 / 15$ になる44,77), 3) システ 厶外への $\mathrm{CO}_{2}$ の流出が少なく, 施用した $\mathrm{CO}_{2}$ の 80 $90 \%$ が植物に光合成により吸収される $\left.{ }^{46,48)}, 4\right)$ 肥料成 分を含んだかん水余剰水がシステム外に排出されないの で，施肥量を節減でき，また排水による環境污染がない， 5)害虫および病原菌の侵入を開放型システムと比較して 阻止しやすく，それゆえ農薬はほぼ不要であり，また， 使用するとしても，閉鎖型であるがゆえにシステム外へ の薬剤の散逸が少なく, 結果として使用量は少なくてす む.

\section{苗生産予測およびシステムの運用・管理}

閉鎖型システムのような環境制御下では, 苗の生育も しくはガス交換特性をシステム内の環境の関数として表 すことが容易である ${ }^{78)}$. これまでに，比較的簡単な数理 モデルを用いて, 閉鎖型システムにおけるサツマイモ苗 個体群の光合成速度 ${ }^{79}$ や蒸発散速度 ${ }^{800}$ の推定, 気流速度 が苗のガス交換におよぼす影響81), 苗の生育予測82)，栄 養繁殖法を用いたときの増殖体生産数予測 ${ }^{83 \sim 87}$ につい てそれぞれ検討してきている. 現在, その精度を上げる ために必要とされる基礎知見も収集している88. これら の研究は, システムの運用・管理面で有益な基礎知見と なるので，今後さらに発展させる必要がある. 
他方，システムの運用・管理技術の良否により，苗の 品質の良否は影響される場合がある。閉鎖型システムに おいては，開放型システムよりもその運用・管理技術は 簡略化しうると考えられるが, さらなる簡略化, 省力化 のためには，コンピュータの利用が必須である，ただし， そのコンピュータは特別なものではなく, 比較的安価な 量販品でも十分である.

\section{今後の課題}

閉鎖型システムの普及のためには，さらなる低コスト 化が必要とされる，実用的なシステムの開発は, 現在の ところ数社で行なわれているが，まだ始まったばかりで あり，依然高価である，導入事例に関しても，ごくわず かである.今後, 閉鎖型システムの苗生産現場へのさら なる普及を図るためには, 不必要な機能を一切省き, よ り低価格で供給されるシステムの開発が必要となる。あ わせて, 開放型システムと比べて, より高品質な苗をよ り低コストで生産できることを実証する必要もある.

ビール工場や食品工場などでは, 製品の生産工程の中 でゴミを排出しないというゼロエミッションがこれまで に達成されている。また，コンピュータ工場や自動車工 場でも，それ目標として揭げられている。 これは，企業 イメージ向上だけではなく廃棄物の処理費用および資材 調達費用も節減できるためである．閉鎖型システムでは, 閉鎖型であるがゆえにゼロエミッションの達成は比較的 容易であると考えられ，コスト削減の上でも，また，シ ステム外周辺に与える影響, すなわち環境污染を最小に する上でも，今後，それを目標とすべきであろう.

現在，あるシステム(例えば，工場など)が周辺の環境 に与える影響の度合いを表すための手法として，ライフ サイクルアセスメント (Life Cycle Assessment, LCA)が 導入されつつある. LCA とは, 製品の原料調達から廃 棄までのそれぞれのステージにおいて，システム外の環 境に与える影響を定量的に把握する手法の 1 つである. 農業分野においても導入されつつあり，水稲生産や，肉 牛生産の分野において LCA が取り組まれている ${ }^{89)}$.今 後，LCAによる閉鎖型システムと開放型システムの評 価を行うことで, 閉鎖型システムで苗を省資源的に生産 できることがより明確になるであろう。

食品工場などの高度な衛生管理を必要とされるところ では, 作業の手順を明確にし, 污染が予想される場所の 重点的な管理を行なうという HACCP(Hazard Analysis and Critical Control Point)が導入されている. 現在 のところ, 苗生産現場における病虫害管理は，その管理
者もしくは個々の生産業者によって異なっていて, 明文 化もしくは標準化されたそのような指標は見あたらない. 閉鎖型システムにおいても, 病害虫に污染されていない ことも重要な苗の品質の 1 つであることから, HACCP と同様の概念で病虫害管理を行なう必要があろう.

\section{おわりに}

閉鎖型システムは従来の苗生産で用いられている温室 のような開放型システムに比較して上述のような多くの 利点を有することから, 今後, 実用的苗生産システムと して普及しうると筆者らは考えている. その根拠として， 1) 苗の品質向上，2)苗あたり資源総使用量の低減, およ び3)それにともなう生産コストの低隇, があげられる. 苗の品質向上は，ここにあげた例だけでも十分その可能 性を示すことができる，今後，さらなる実証試験により， より明確にできるであろう。苗あたり資源総使用量は, 閉鎖型システムの方が開放型システムより低くなり得る. まだ実験的には証明されていない部分もあるが，水およ び $\mathrm{CO}_{2}$ 輸送に関する結果より推測すると, 閉鎖型シス テムの方が開放型システムより苗あたり資源総使用量は 小さくなると予想される。詳細なコスト試算に関しては 今後の課題ではあるが, 本稿に示した程度の単純な試算 を行なった場合でも，十分にその実用化の可能性を示す ことができる. 若干の課題は残されているが, 早期に解 決しえるものばかりである。 それらを解決していくこと で, 比較的近い将来, 閉鎖型システムの苗生産現場への 導入が行なわれ, 高品質な苗がより安価に流通すること を望む.

\section{謝辞}

東海大学開発工学部の星 岳彦氏には, 本稿作成時に 有益なご意見をいただいた。ここに，感謝の意を表する.

\section{引用文献}

1）古在豊樹：閉鎖型苗生産システムの開発と利用一 食料・環境・エネルギ問題の解決を目指して一, 養賢堂, pp. 1-191(1999)

2）古在豊樹：新しい植物生産システムとその研究方 向・課題の展望〔1〕一環境調節工学の立場から 一，農業および園芸，71(1)：10-14(1996)

3）古在豊樹：新しい植物生産システムとその研究方 向・課題の展望〔2〕一環境調節工学の立場から 一，農業打よび園芸，71(2)：243-248(1996) 
4）全 昶厚：優良均質苗を育てる人工照明苗プラン 卜，照明学会誌，85(3)：213-216(2001)

5) Chun, C. and Kozai, T. : A closed transplant production system, a hybrid of scaled-up micropropagation system and plant factory, J. Plant Biotechnology, 3(2) : 59-66(2001)

6) 古在豊樹：植物組織培養の新段階一培養器環境加 ら地球環境へ一，農山漁村文化協会，pp. 1-172 (1998)

7) Kozai, T.: Transplant production under artificial light in closed systems, Proc. the 3rd Asian Crop Science Conference, Taichung, Taiwan : 296-308(1998)

8) Kozai, T., Ohyama, K., Afreen, F., Zobayed, S., Kubota, C., Hoshi, T. and Chun, C. : Transplant production in closed systems with artificial lighting for solving global issues on environmental conservation, food, resource, and energy, Proc. ACESYS III Conference-from protected cultivation to phytomation-, Rutgers University, New Jersey, USA : $31-45$ (1999)

9）古在豊樹・全 乘厚・大山克己：閉鎖型苗生産シ ステムの開発と利用，SHITA REPORT NO. 16 植物工場の最新技術 その $2: 14-29(2000)$

10）古在豊樹・全 香厚・大山克己：新たな苗生産シ ステムの構築を目指して〔1〕一閉鎖型苗生産シ ステムの提案一, 農業および園芸, 75(3)：371$377(2000)$

11）古在豊樹・全 昶厚・大山克己：新たな苗生産シ ステムの構築を目指して〔2〕一閉鎖型苗生産シ ステムの提案一，農業および園芸，75(4)：453$458(2000)$

12) Kozai, T. : A closed system for mass production of transplants with minimum resources and environmental pollution, Proc. Intl. Sympo. Trends in plant cell culture and biotechnology for plant production and crop improvement, Bangkok, Thai land : 1-17 (2000)

13) Kozai, T., Chun, C., Kubota, C. and Ohyama, $\mathrm{K}$. : Transplant production in closed systems with artificial lighting for solving global issues on environmental conservation, food, resource, and energy, Proc. ACESYS IV ConferenceEnvironmentally friendly High - Tech Controlled Environment Agriculture-, Tsukuba, Ibaraki, Japan : 110-126 (2000)

14) Kozai, T., Chun, C., Islam, A.F.M.S. and Ohyama, K. : Efficient production of sweetpotato (Ipomoea batatas (L.) Lam.) propagules and transplants using single node leafy cuttings in closed systems with artificial lighting, Proc. Intl. workshop on sweetpotato cultiver decline study, Miyakonojyo, Miyazaki, Japan : 106-115(2000)

15) Kozai, T., Kubota, C., Chun, C., Afreen, F. and Ohyama, K. : Necessity and concept of the closed transplant production system, In : Kubota, C. and Chun C. (eds.), Transplant Production in the 21st Century, Kluwer Academic Publishers, pp. 3-19 (2000)

16) Kozai, T. Kubota, C., Chun, C. and Ohyama, $\mathrm{K}$. : Closed transplant production systems with artificial lighting for quality control, resource saving and environment conservation, Proc. The XIV memorial CIGR world congress 2000, Tsukuba, Ibaraki, Japan : 103-110(2000)

17）古在豊樹：省資源 - 環境保全的閉鎖型植物生産シ ステム，生物と気象，1(1)：13-16(2001)

18）古在豊樹：熱帯における森林資源の保全・再生と その多目的利用 熱帯林保全・植林に関する植物 環境工学的アプローチ, 熱帯農業, 45(5)：308314 (2001)

19) Kozai, T. and Chun, C. : Closed systems with artificial lighting for production of high quality transplants with minimum resource and environmental pollution, Proc. Intl. Symposium on Design and Environmental Control of Tropical and Subtropical Greenhouses, Taichung, Taiwan : 77-84 (2001)

20）大山克己：植物苗生産システム, (社)農業電化協 会編, 知っておきたい農業電化の先端技術用語 テクノワード，農業電化協会，pp. 54-55(2001)

21）池田 彰 - 谷村泰宏 - 江崎謙治 - 河相好孝 - 中山 繁樹・岩尾憲三：蛍光ランプを光源とした人工光 型植物工場の開発一近接照射による照明電力の低 減一，植物工場学会誌，3(2)：111-123(1992)

22）谷村泰宏・池田 彰：蛍光ランプを光源とする植 物栽培システムの照明設計, CELLS 研究会誌, 5 (2) : 7-10 (1993)

23) Kitaya, Y., Niu, G., Kozai, T. and Ohashi, M. : Photosynthetic photon flux, photoperiod, and $\mathrm{CO}_{2}$ concentration affect growth and morphology of lettuce plug transplants, HortScience, 33 (6) : 988-991 (1998)

24）大村好孝・大嶋好衣・古在豊樹：連続光照射下に おける変温処理はトマト実生の第一花房の着生葉 位の低下とクロロシスの回避を可能とするか, 関 東の農業気象，26：26-27(2000)

25）大村好孝 -大嶋好衣 -久保田智惠利 - 古在豊樹： 連続光照射下における変温処理がナス, ピーマン およびトマト実生の生育に及ぼす影響, 農業環境 工学関連 4 学会 2001 年合同大会：50(2001)

26) Omura, Y., Oshima, Y., Kubota, C. and Kozai, $\mathrm{T}$.: Treatments of fluctuating temperature under continuous light enabled the production of quality transplants of tomato, eggplant and sweet pepper, HortScience, 36:586(2001)

27）大山克己 - 真辺幸治 - 大村好孝 - 久保田智惠利 古在豊樹：閉鎖型苗生産システムと開放型苗生産 システムの夏季におけるトマトセル成型苗の品質 と資源消費量の比較例, 生物環境調節 (2002, 投 稿中)

28）鈴木光則 - 全 昶厚 - 古在豊樹：閉鎖型苗生産シ 
ステムに関する研究 3 . 深夜電力利用によるトマ 卜セル成型苗生産, 日本植物工場学会平成 10 年 度大会講演要旨 : 52-53(1998)

29）大村好孝・古在豊樹：48 時間明暗周期における 明期・暗期気温差がトマト実生の茎長および乾物 重に及ぼす影響, 関東の農業気象, 26:28-29 (2000)

30）大村好孝・戸井田宏美・古在豊樹：非周期的およ び周期的明暗下におけるトマト実生の生育, 農業 環境工学関連 4 学会 2001 年合同大会：67 (2001)

31）大村好孝・戸井田宏美 - 古在豊樹：連続明期下に おいて 24 時間の温度周期はトマト実生の生長を 最大とするか, 農業環境工学関連 4 学会合同大会 2002 年度大会講演要旨：193(2002)

32）阿南純一・全 香厚 - 古在豊樹：24 時間に限定 しない明暗周期下におけるホウレンソウの抽だい および花芽の発達, 農業環境工学関連 4 学会 2002 年合同大会講演要旨集：194(2002)

33）全 䅛厚 - 古在豊樹 - 阿南純一 - 渡辺 歩 - 樋川 亘：自然界に存在し得ない環境条件下における植 物生育一明暗周期と植物苗の花成を中心に一, 農 業環境工学関連 4 学会 2002 年合同大会講演要旨 集：359(2002)

34) Chun, C. and Kozai, T. : Closed transplant production system at Chiba University, In : Kubota, C. and Chun C. (eds.), Transplant Production in the 21st Century, Kluwer Academic Publishers, pp. 20-27 (2000)

35）全 租厚 - 古在豊樹 - 布施順也：小規模閉鎖型苗 生産システムの開発, 農業環境工学関連 4 学会合 同大会 2001 年度大会講演要旨集：318(2001)

36）岡部勝美 -土屋 和・布施順也 -中南暁夫：人工 光閉鎖型苗生産装置の開発とその応用, SHITA REPORT NO. 18 植物工場をとりまく最新テク ノロジー：14-29(2002)

37）大山克己 - 横井真悟 - 長谷川智行 - 古在豊樹 - 久 保田智惠利・全 或厚：閉鎖型苗生産システムに おける物理環境要素の空間的微少変動と苗の生育 のばらつきとの線形重回帰分析, 農業環境工学関 連 4 学会合同大会 2002 年度大会講演要旨：186 (2002)

38）村瀬治比古：プラグトレイ用噴射式底面灌水装置 の開発，日本農業気象学会 1999 年度全国大会・ 日本生物環境調節学会 1999 年大会合同大会講演 要旨：328-329 (1999)

39) Murase, H. : Microprecision irrigation system for transplant production, In : Kubota, C. and Chun, C. (eds.), Transplant Production in the 21st Century, Kluwer Academic Publishers, pp. 33-37 (2000)

40）大山克己- 横井真悟 - 長谷川智行 - 村瀬治比古 : 噴射式底面かん水装置の利用 その 1 初期噴射 圧力と電磁弁開放時間がかん水量におよぼす影響, 農業環境工学関連 4 学会合同大会 2002 年度大会 講演要旨：168(2002)

41）大山克己 - 横井真悟 - 長谷川智行 - 村瀬治比古 : 噴射式底面かん水装置の利用 その 2 トマトセ
ル成型苗育成期間中の培地の体積含水率制御，農 業環境工学関連 4 学会合同大会 2002 年度大会講 演要旨：169(2002)

42）西村将雄 - 古在豊樹 - 久保田智惠利 - 全 或厚： 実用規模閉鎖型苗生産システムのエネルギ収支, 植物工場学会誌，13(4)：254-261(2001)

43）大山克己・吉永慶太・古在豊樹：閉鎖型苗生産シ ステムのエネルギおよび物質収支(第 1 報)一工ネ ルギ収支一，植物工場学会誌，12(3)：167-170 (2000)

44）大山克己・吉永慶太・古在豊樹：閉鎖型苗生産シ ステムのエネルギおよび物質収支(第 2 報) 一水収 支一，植物工場学会誌，12(4)：217-224(2000)

45）大山克己 - 長谷川智行 - 横井真悟 - 古在豊樹 - 久 保田智惠利・全 和厚：閉鎖型苗生産システムに おける水収支の苗の生育にともなう変化，農業環 境工学関連 4 学会合同大会 2002 年度大会講演要 旨：188(2002).

46）大山克己・長谷川智行 - 横井真悟 - 古在豊樹 - 久 保田智惠利・全 租厚：閉鎖型苗生産システムに おける二酸化炭素収支の苗の生育にともなう変化, 農業環境工学関連 4 学会合同大会 2002 年度大会 講演要旨 : 189 (2002)

47）大山克己 - 横井真悟 - 長谷川智行 - 古在豊樹 - 久 保田智惠利・全 租厚：閉鎖型苗生産システムに おけるエネルギ収支の苗の生育にともなう変化, 農業環境工学関連 4 学会合同大会講演要旨：187 (2002).

48）吉永慶太・大山克己・古在豊樹：閉鎖型苗生産シ ステムのエネルギおよび物質収支(第 3 報) 一二酸 化炭素収支一，植物工場学会誌，12(4)：225-231 (2000)

49）長谷川智行 - 横井真悟 - 酒見幸助 - 林 泰正 - 星 岳彦・久保田智惠利・全 昶厚・古在豊樹：自立 分散制御を用いた苗工場生産管理システムの栽培 試験, 農業環境工学関連 4 学会合同大会 2001 年 度大会講演要旨：325(2001)

50）林 泰正・星 岳彦・古在豊樹：大規模植物増殖 施設における受注・生産管理支援システム，日本 農業気象学会 1999 年度全国大会・日本生物環境 調節学会 1999 年大会合同大会：408-409(1999)

51）林 泰正・星 岳彦・古在豊樹：大規模植物増殖 施設における受注・生産管理システム, SHITA REPORT NO.16 植物工場の最新技術 その $2: 1-13(2000)$

52）林 泰正・星 岳彦・古在豊樹：大規模植物苗生 産施設のための受注・生産管理システム，農業お よび園芸，75(11)：1165-1174(2000)

53）林 泰正・星 岳彦・古在豊樹：自律分散制御を 用いた大規模苗工場生産支援システムの開発，農 業環境工学関連 4 学会合同大会 2002 年度大会講 演要旨: $323(2002)$

54) Hoshi, T., Hayashi, Y. and Kozai, T. : Design concepts of computerized support systems for large-scale transplant production, In : Kubota, C. and Chun C. (eds.), Transplant Production in the 21st Century, Kluwer Academic Publishers, 
pp. $38-43(2000)$

55）星 岳彦・林 泰正・古在豊樹：個体群を管理単 位とした生産支援システムの提案, 農業環境工学 関連 4 学会合同大会 2001 年度大会講演要旨：322 (2001)

56）横井真悟・長谷川智行 - 林 泰正 - 星 岳彦 - 田 口勝則・久保田智惠利 - 全 香厚 $\cdot$ 古在豊樹：自 律分散制御による苗工場生産管理システムの動作 特性, 農業環境工学関連 4 学会合同大会 2002 年 度大会講演要旨：324(2001)

57) Matsuura, Y., He D. and Kozai, T. : Development of transplant population analysis system, Intl. Ann. Meeting ASAE, Sacramento, California, USA. Paper No. 017051.(2001)

58) He, D., Hirafuji, M. and Kozai, T. : Improvement of a binocular stereovision system by using artificial neural networks, J. SHITA, 14 (1) $: 18-24(2002)$

59）土屋 和・布施順也 - 岡部勝美 - 全 昶厚 - 古在 豊樹：閉鎖型苗生産システムにおけるセルトレイ 育苗のための自動灌水方法, 農業環境工学関連 4 学会 2001 年合同大会：320(2001)

60）山本修司：照明の省エネルギを考えるための照明 の量と質の基本知識, 鉄道と電気技術 $9(12): 5$ 11(1998)

61）大山和伸：省エネルギ-エアコンの開発, 電学論 $\mathrm{D}, 118(6)$ : 813(1998)

62）金子賢一・渋谷俊夫・古在豊樹：閉鎖型苗生産シ ステムに関する研究. 1. トマトセル成型苗の生 育特性, 日本植物工場学会平成 10 年度大会講演 要旨：48-49(1998)

63) Ohyama, K., Fujiwara, M., Kozai, T. and Kimura, H. : Growth and development of transplants in a closed-type transplant production system, Intl. Ann. Meeting ASAE, Milwaukee, Wisconsin, USA. Paper No. 004084 (2000)

64）大山克己・藤原雅哉・古在豊樹・全 暞厚：閉鎖 型苗生産システムのナスセル成型苗育成時におけ る電気エネルギおよび水消費量, 植物工場学会誌, 13 (1) : 1-6(2001)

65）大山克己 - 古在豊樹 - 久保田智惠利 - 全 永厚 長谷川智行・横井真悟 - 西村将雄 : 閉鎖型苗生産 システムに設置した家庭用エアコンの冷房時成績 係数, 植物工場学会誌, $14(3)$ ：141-146(2002)

66) He, D., Lok, Y.H., Chun, C. and Kozai, T. : Yield and growth of sweetpotato using plug transplants as affected by cell volume of plug tray and type of cutting, In : Kubota, C. and Chun C. (eds.), Transplant Production in the 21st Century, Kluwer Academic Publishers, pp. 154-159 (2000)

67) Chun, C., Kozai, T., Kubota, C. and Okabe, K. : Manipulation of bolting and flowering in spinach (Spinacia oleracea L.) transplant production system, Acta Hort, 515:201-206 (2000)

68) Chun, C., Watanabe, A., Kim, H-H., Fuse, J. and Kozai, T. : Bolting and growth of Spinacia oleracea L. can be altered by modifying the photoperiod during transplant production, HortSciene, 35(4) : 624-626(2000)

69) Chun, C., Tominaga, M. and Kozai, T. : Effects of photoperiod and carbon dioxide concentration during transplant production on floral development and bolting of Spinacia oleracea L., Environ. Control in Biol., 39 (2) : 87-94 (2001)

70) Chun, C., Tominaga, M. and Kozai, T. : Floral development and bolting of Spinacia oleracea $\mathrm{L}$. as affected by photoperiod and integrated photosynthetic photon flux during transplant production, HortScience, 36 (5) : 889-892(2001)

71) Kim, H-H., Chun, C., Kozai, T. and Fuse, J. : The potential use of photoperiod during transplant production under artificial lighting conditions on floral development and bolting, using spinach as a model, HortScience, 35 (1) : 43-45 (2000)

72) Kim, H-H. and Kozai, T.: Production of value - added tranplants in closed systems with artificial lighting, In : Kubota, C. and Chun C. (eds.), Transplant Production in the 21st Century, Kluwer Academic Publishers, pp. 137-144 (2000)

73）布施順也・土屋 和・岡部勝美・全 昶厚・古在 豊樹：閉鎖型苗生産システムにおける高品質パン ジ一苗生産, 農業環境工学関連 4 学会合同大会 2001 年度大会講演要旨：319 (2001)

74) Omura, Y., Chun, C., Kozai, T., Arai, K. and Okabe, K. : High quality plug - transplants produced in a closed system enables pot - transplant production of pansy in the summer, In : Kubota, C. and Chun C. (eds.), Transplant Production in the 21st Century, Kluwer Academic Publishers, pp. 145-148(2000)

75）西村将雄・古在豊樹 - 久保田智惠利・全 求厚： 閉鎖型苗生産システムにおける消費電力量および 電力コストの解析, 植物工場学会誌, 13 (3)：204 -209 (2001)

76）大山克己・古在豊樹：人工光型植物工場における 消費電力量と電力料金の試算例, 植物工場学会誌, 10(2) : 96-107 (1998)

77) Ohyama, K., Fujiwara, M., Kozai, T. and Kimura, H. : Water consumption and utilization efficiency of a closed-type transplant production system, Intl. Ann. Meeting ASAE, Milwaukee, Wisconsin, USA, Paper No. 004085 (2000)

78) Kubota, C. : 2000. Modeling and simulation in transplant production under controlled environment, In: Kubota, C. and Chun, C. (eds.), Transplant Production in the 21st Century, Kluwer Academic Publishers, pp. 47-52 (2000)

79）山田千佳子・大山克己・古在豊樹：閉鎖型苗生産 システムにおける電気エネルギ消費量削減のため の光合成有効光量子束調節, 生物環境調節, 38 
(4) : 255-261 (2000)

80) Bostick, W.M., Kubota, C., Abdel-Ghany, A.M. and Kozai, T.: A preliminary experiment to simulate evapotranspiration rate of plug transplant trays in a closed transplant production system, Proc. Intl. Sympo. Design and Environ. Control of Trop. and Subtrop. Greenhouses, Taichung, Taiwan: 53(2001)

81) Chintakovid, W., Kubota, C., Bostick, W.M. and Kozai, T. : Effect of air current speed on evapotranspiration rate of transplant canopy under artificial light, J. SHITA, 14(1) : 25-31 (2002)

82）山田千佳子・大山克己・古在豊樹：閉鎖型苗生産 システムにおけるサツマイモ植物個体群の純光合 成速度の経日変化, 生物環境調節, 38(4)：247$254(2000)$

83) Kubota, C. and Kozai, T. : Use of transition matrix models for transplant production under controlled environments, Intl. Ann. Meeting ASAE, Toronto, Ontario, Canada, Paper No. 995061 (1999)

84) Kubota, C. and Kozai, T. : Development of a mathematical model for vegetative propagation: Simulated sweetpoteto cutting production as affected by propagation methods and environment conditions, Acta Hortic, 519:65-72 (2000)

85) Kubota, C. and Kozai, T.: Mathematical models for planning vegetative propagation under controlled environments, HortScience, 36 (1) : 15-19(2001)

86）ロク・イイ・ヒン・大山克己・久保田智恵利・古 在豊樹：閉鎖型苗生産システムにおけるサツマイ モ増殖体生産速度と消費電力量に及ぼす栽植密度 の影響, 植物工場学会誌, 14(1)：10-17(2002)

87）ロク・イイ・ヒン・大山克己・久保田智恵利・古 在豊樹：閉鎖型苗生産システムにおけるサツマイ モ増殖体生産速度と消費電力量に及ぼす増殖法の 影響，生物環境調節，40(3)：311-316(2002)

88）藤原雅哉・古在豊樹：明期と暗期におけるサツマ イモ単節挿し穂苗の葉身生長, 熱帯農業 45 (Extra issue 2)：91-92(2001)

89）農林水産省農業環境技術研究所編：農業における ライフサイクルアセスメント, 養賢堂, pp. 1$125(2000)$ 